\title{
National-level integrative ecological health assessments based on the index of biological integrity, water quality, and qualitative habitat evaluation index, in Korean rivers
}

\author{
Jae Hoon Lee ${ }^{1}$, Jeong-Ho Han ${ }^{1}$, Hema K. Kumar ${ }^{1}$, Jun-Kil Choi ${ }^{2}$, Hwa Kun Byeon ${ }^{3}$, \\ Jaeseok Choi ${ }^{4}$, Jai-Ku Kim ${ }^{5}$, Min-Ho Jang ${ }^{6}$, Hae-Kyung Park ${ }^{7}$ and Kwang-Guk An ${ }^{1 *}$ \\ ${ }^{1}$ Department of Biological Science, School of Biological Sciences and Biotechnology, Chungnam National University, \\ Daejeon 305-764, Republic of Korea \\ 2 Department of Biological Science, Sangji University, Wonju 220-702, Republic of Korea \\ 3 Department of Biological Education, Seowon University, Cheongju 361-742, Republic of Korea \\ ${ }^{4}$ Institute of Environmental Research, Department of Biology, Kangwon National University, Chuncheon 200-701, \\ Republic of Korea \\ 5 Chungrok Environmental Ecosystem Research Institute, Anyang 431-070, Republic of Korea \\ ${ }^{6}$ Department of Biological Education, Kongju National University, Gongju 314-701, Republic of Korea \\ 7 Water Environment Research Department, The National Institute of Environmental Research, Incheon 404-170, Republic of Korea
}

Received 1 September 2010; Accepted 7 March 2011

\begin{abstract}
The objectives of this study were to evaluate fish guild compositions and national river health using a multi-metric model of the Korean index of biological integrity using fishes (K-IBIF) in four major Korean watersheds along with water chemistry and habitat quality. Tolerant and omnivore fish species dominated all the watersheds, and the proportions of tolerance guilds and trophic guilds reflected water chemistry and habitat quality. The number of sensitive species and insectivore species had negative correlations $(r<-0.42, P<0.01)$ with chemical water quality (biological oxygen demand (BOD)), while tolerant species and omnivore species had positive correlation $(r>0.27, P<0.05)$ with BOD values. Physical habit conditions, based on qualitative habitat evaluation index (QHEI) model, indicated a "good" condition ( $m e a n=68.9$; range $=45-105)$ in three watersheds, except for the Yeongsan River watershed. Values of QHEI were significantly correlated $\left(R^{2}>0.4, P<0.01\right)$ with nitrogen and phosphorus levels in all watersheds, suggesting that habitat degradation is associated with eutrophication. Model values of K-IBIF in the watersheds averaged 18.2, indicating a "fair" condition, and about $37 \%$ of all observations in K-IBIF model values were judged as a "poor" health condition, indicating severe health impairment. Overall, our data suggest that degradation of the river health was due to a combined effect of chemical pollution and physical habitat modifications. This research provides valuable information on Korean river conservation and restoration in the future.
\end{abstract}

Key words: River health condition / K-IBIF model / physical habitat condition / water quality

\section{Introduction}

The advent of our recent industrial revolution has taken its toll on the aquatic ecosystem in Korea. Lotic ecosystems have been subject to both chemical and habitat degradation (Lee, 2001; Kwon and An, 2006; Lee and An, 2007; Lee and An, 2010). Across the world similar environmental degradation has been associated with reduced species diversity of phytoplankton, zooplankton, macroinvertebrates, and fishes (Karr et al., 1985a, 1985b),

\footnotetext{
*Corresponding author: kgan@cnu.ac. kr
}

increased dominance of pollution-tolerant fish, frequent algal blooms (Olguin et al., 2000), extinction of sensitive species and endemic species (Karr et al., 1985a, Limburg and Schmidt, 1990), and overall decreased ecological health of the aquatic ecosystems (Karr et al., 1985a, 1985b; Morley and Karr, 2002).

Developing regionally appropriate quantitative tools for diagnosing ecosystem health is a pressing need in Korea. Previously, most degradation was assessed on the basis of conventional chemical analyses (Yoder, 1991). Most chemical approaches detect degradation associated with eutrophication or toxicants, but do not emphasize 
the alterations of the stream environment (Boon, 2000; An and Lee, 2006). Complex effects arising from channelization, barriers, or altered flow regimes (Fore et al., 1993) are ignored, hence the need for an integrated approach using biological, chemical, and physical habitat parameters to support efficient stream health monitoring and management (Karr, 1981; Gore, 1985; Brookes and Shields, 1996).

Alteration of habitat can significantly influence the stream biota (Karr et al., 1986). Thus, habitat is directly related with biological diversity in lotic ecosystems (Raven et al., 1998). Environmentally advanced countries such as United States, Canada, and the European Union countries have been evaluating their physical habitat condition using various habitat quality indices (HQIs; Binns and Eiserman, 1979) and the biotic condition index (BCI; Winget and Mangum, 1979) for over 30 years. Later, the US Environmental Protection Agency (EPA) developed a "rapid bioassessment protocol" (RBP; Barbour et al., 1999) for assessing stream health conditions based on the originally developed index of biological integrity (IBI) of Karr (1981), where the concept of the qualitative habitat evaluation index (QHEI) was introduced by Plafkin et al. (1989). The key biota used in the RBP are periphyton, as an indicator of primary producer (Kelly and Whitton, 1995; Kelly et al., 1998; Barbour et al., 1999; US EPA, 2002), macroinvertebrates as an indicator of primary consumers (Plafkin et al., 1989; Barbour et al., 1999), and fish as an indicator of primary and secondary consumers (Lang et al., 1989; DIN 38410, 1990; US EPA, 1993; Lang and Reymond, 1995). This model reflects changes in the guild structure viz., number of sensitive species (Bae and An, 2006; Lee and An, 2007), tolerant species (Desirree et al., 2006; Walton et al., 2007), exotic species (Leidy and Fiedler, 1985), feeding guilds (Barbour et al., 1999), and morphological anomalies (An et al., 2004).

An IBI-type model using fish assemblages has been adapted by many countries worldwide: North America (Karr and Dionne, 1991; US EPA, 1993), Europe (EU Water Framework Directive; European Commission, 2000), South America (Lyons et al., 1995; Soto-Galera et al., 1998), and Africa (Hugueny et al., 1996; Kleynhans, 1999). However, there are very few health-assessment models in Asia (Japan: Rossano, 1996; Koizumi and Matsumiya, 1997; China: Zhu and Chang, 2008). The IBI concept was first introduced in Korea to evaluate one of the most urban-influenced Keum-Ho River by Yeom et al. (2000). It has now been widely applied to the major watersheds viz., Han River (An et al., 2001a), Geum River (An et al., 2001b), and Nakdong River watersheds (Kwon and An, 2006; Han et al., 2007). Recently, a national stream-health assessment methodology using biota, such as diatom (Hwang et al., 2006), macroinvertebrate (Won et al., 2006), and fish (An et al., 2006) was developed by the Ministry of Environment in Korea (MOE/NIER, 2006) to evaluate the aquatic ecosystem. It provides standards on the management and restoration of the impacted stream health in the major watersheds in Korea. Based on this methodology, a national monitoring program was established in 2007.
The objectives of this study were to evaluate fish-guild compositions and national level ecological health in four major Korean watersheds using a multi-metric fish model of Korean index of biological integrity using fish (K-IBIF). Also, we evaluated water quality using chemical parameters and physical habitat health, based on a QHEI model for comparisons with K-IBIF model values. These results provide valuable information for effective management and restoration of impaired Korean rivers in the future.

\section{Materials and methods}

\section{Study sites}

This study was conducted in the four major river watersheds of Korea $\left(34-42^{\circ} \mathrm{N}, 124-130^{\circ} \mathrm{E}\right)$ : the Han River (HR, length [L], $514 \mathrm{~km}$; basin area [BA], $26219 \mathrm{~km}^{2}$ ), the Nakdong River (NR, L, $525 \mathrm{~km}$; BA: $23860 \mathrm{~km}^{2}$ ), the Geum River (GR, L, $414 \mathrm{~km}$; BA, $9886 \mathrm{~km}^{2}$ ), and the Yeongsan River (YR, L, $115 \mathrm{~km}$; BA, $3371 \mathrm{~km}^{2}$ ) watersheds (Fig. 1) during 2008-2009. In total, 52 sites consisting of first- through fourth-order streams (Strahler, 1957) were sampled for the four major river watersheds; 15 sites in the Han River (H1-H15), 14 sites in the Nakdong River (N1-N14), 13 sites in the Geum River (G1-G13) and 10 sites in the Yeongsan River (Y1-Y10).

\section{Fish sampling}

Fish sampling was conducted twice in the four watersheds in 2008 and 2009, respectively. Fish sampling approach was followed by a modified protocol of the Ohio EPA method (1989). Sampling gears used were casting nets (mesh size, $5 \times 5 \mathrm{~mm} ; 1.5 \mathrm{~m} \times 1.5 \mathrm{~m} \times 3.14 \mathrm{~m}$ ) and kick nets (mesh size, $4 \times 4 \mathrm{~mm}, 1.8 \mathrm{~m} \times 0.9 \mathrm{~m}$ ), the most common sampling gears used for wading streams. Casting net was applied to habitats with unobstructed open water viz., riffles, pools, and slow runs, and kick net was used in sites subject to fast current regime and with obstructions, where it is difficult to use a casting net. Fish sampling and handling techniques were based on catch per unit effort (CPUE) methods (US EPA, 1993), with a sampling period of $50 \mathrm{~min}$ at each location. Fish were collected from all types of habitats, including riffles, runs, and pools, using the wading method (Ohio EPA, 1989). In addition, fish samples were collected from 39 reference streams within the watersheds to derive a maximum species richness regression against stream order. The reference streams were selected based on the approach of Hughes et al. (1994). All specimens were preserved in neutral buffered $10 \%$ formalin and sent to the laboratory for identification (Kim and Park, 2002; Lee and No, 2006). The external characteristics of individual fish were examined in the laboratory for deformities (D), erosions (E; skin, barbells), lesions (L; open sores, ulcerations) and tumors (T) (DELT; Sanders et al., 1999). The guild 


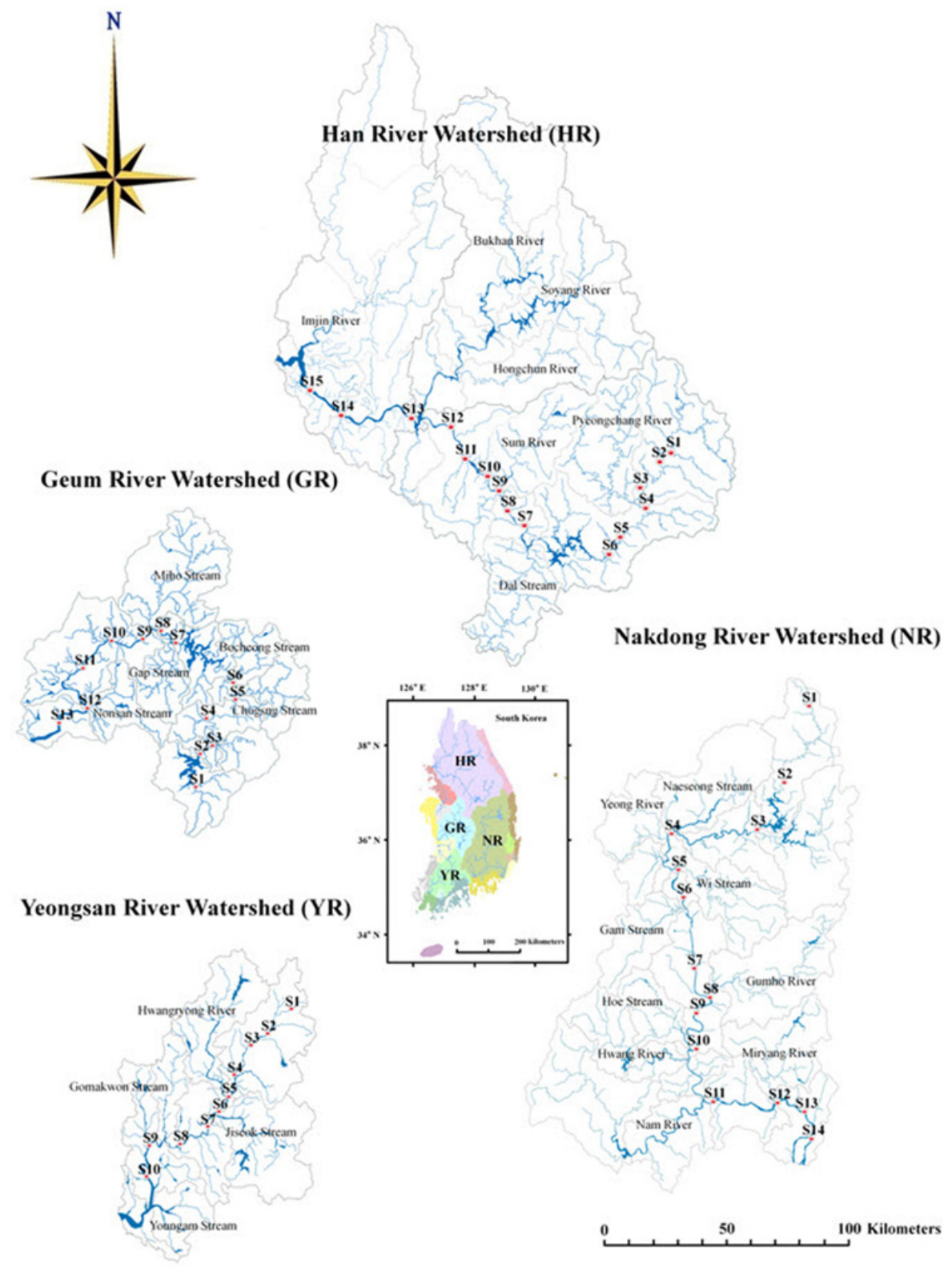

Fig. 1. Sampling sites of the four major river watersheds in Korea.

structure was analyzed based on the previous regional studies (An et al., 2004).

\section{Analysis of water quality parameters}

Sampling for water quality was conducted twice at the same time as for fish sampling per watershed in 2008 and 2009. Ten parameters of the physico-chemical water quality data for the years 2008-2009 viz., water temperature $\left({ }^{\circ} \mathrm{C}\right)$, conductivity, biological oxygen demand (BOD), chemical oxygen demand (COD), suspended solids (SS), total phosphorus (TP), ammonia nitrogen $\left(\mathrm{NH}_{3}-\mathrm{N}\right)$, nitrate nitrogen $\left(\mathrm{NO}_{3}-\mathrm{N}\right)$, ortho phosphorus $\left(\mathrm{PO}_{4}-\mathrm{P}\right)$, and total nitrogen $(\mathrm{TN})$ were examined for the analyses. Water temperature and conductivity was measured at the time of sample collection with YSI sonde 6600 . TN was measured by second derivative method after a persulfate digestion (Crumpton et al., 1992). TP was determined using the ascorbic acid method after persulfate oxidation (Prepas and Rigler, 1982). SS, BOD, and COD were measured by the Standard Methods (APHA, 2005). Nutrient analyses were performed thrice, and $\mathrm{BOD}, \mathrm{COD}$, and SS were measured twice (MOE, 2000; APHA, 2005).

\section{Analysis of physical habitat}

Physical habitat qualities at the sampling sites were assessed using a multi-metric model of QHEI. The original 11-metric model (Plafkin et al., 1989; Barbour et al., 1999) was modified as a six-metric model for regional 
application (MOE/NIER, 2006, 2008). For the habitat assessments, the primary, secondary, and tertiary components were included to the model and their metrics were composed of substrate structure and vegetation coverage, channel characteristics, bank characteristics, and bank structure. All the metric characteristics have been previously described in An et al. (2006) and MOE/NIER (2008). The six metrics, M1-M6, evaluate the epifaunal substrate cover, pool substrate, channel flow status, channel alteration, and sediment deposition. An additional metric was also included to account for the effects of dam construction. The health conditions of the habitat were evaluated by summing the scores obtained from the six parameters and then categorizing the system as "excellent" (A; score 120-96), "good" (B; 80-66), "fair" (C; 60-36), and "poor" (30-6) based on the recommendations of MOE/NIER (2008).

\section{Model development of ecological river health}

Multi-metric fish model was developed for diagnosis of the ecosystem health in four major Korean rivers. Our model, K-IBIF, which was based on the IBI concept (Karr, 1981; Karr et al., 1986), was modified from the original US EPA (1994) model and the regional model of An et al. (2006). We adapted an eight-metric system including various attributes such as fish species compositions (M1-M3), trophic composition (M4, M5), fish abundance and health (M6-M8) and for the regional assessments based on the recommendations of Choi et al. (2011), and MOE/NIER (2008). Ratings of 5, 3, and 1 were assigned to each metric (Barbour et al., 1999) according to whether its value approximated, deviated from, or greatly deviated from the expected value in the 10-metric rating. The sum of the ratings, evaluated by maximum species richness line MSRL (Rankin and Yoder, 1999), provides a K-IBIF value for each watershed. The $\mathrm{K}$-IBIF scores were judged as four categories, excellent (A; 46-36), good (B, 35-26), fair (C, 25-16), and poor (D, 15-8). "A" is comparable to a pristine natural state and shows an exceptional assemblage of sensitive species, while " $D$ " shows few species and individuals and a high frequency of tolerant and diseased fish.

\section{Data analyses}

We conducted simple regression analysis and Pearson's correlation analysis (for Windows ver. 12.0; SPSS, 2004) using data of 52 sampling sites. In these analyses, we calculated regression coefficients $\left(\mathrm{R}^{2}\right)$ and equations in the statistical probability $(P)$ significance of 0.05 , and correlation coefficients $(r)$. In addition, statistical package of PC-ORD for Windows ver. 4.25 (McCune and Mefford, 1999) was used for principal components analysis (PCA) to elucidate some relations between the ecological health conditions and physico-chemical factors. This statistical analysis of PCA was used to identify primary import factors in explaining independent effects of QHEI, river order, and water quality parameters on ecological health of K-IBIF. In addition, cluster analysis was conducted by dendrogram approach (PC-ORD; McCune and Mefford, 1999) using similarity coefficients between the functional distances. Data log-transformation was not conducted as shown in statistical approach of US EPA (1994) and site differences in the cluster analysis were tested by unpaired $t$-tests between the two groups.

\section{Results and discussion}

\section{Physico-chemical water quality}

Overall, chemical water quality of the four major Korean watersheds varied largely depending on the watershed, stream order, and the pollution source of urban wastewater. TP was average $146.6 \mu \mathrm{g} . \mathrm{L}^{-1}$ during the study, ranging between 16 and $840 \mu \mathrm{g} . \mathrm{L}^{-1}$, and TN at each sampling site was greater than $1.5 \mathrm{mg} . \mathrm{L}^{-1}$ (mean: $\left.3.78 \pm 1.34 \mathrm{mg} . \mathrm{L}^{-1}\right) . \mathrm{NH}_{3}-\mathrm{N}$ and $\mathrm{NO}_{3}-\mathrm{N}$ accounted for $>90 \%$ of TN, suggesting a hypereutrophic state. The nutrient levels (TP and TN) showed two-fold higher in the Yeongsan River watershed (mean: TP: $356.05 \mu \mathrm{g} . \mathrm{L}^{-1}$; TN: $5.78 \mathrm{mg} . \mathrm{L}^{-1}$ ) compared to the other watersheds (TP: $97.21 \mu$ g.L ${ }^{-1}$; TN: $3.11 \mathrm{mg} . \mathrm{L}^{-1} ; t>2.7, P<0.02$ ), indicating a hyperteurophic condition according to the criteria of Nurnberg (1996). Additionally, all values of $\mathrm{BOD}, \mathrm{COD}, \mathrm{NH}_{3}-\mathrm{N}, \mathrm{NO}_{3}-\mathrm{N}$, and $\mathrm{PO}_{4}-\mathrm{P}$ in the Yeongsan River watershed (means: $4.5 \pm 2.5$ mg. $\mathrm{L}^{-1}, 6.1 \pm$ $1.8 \mathrm{mg} . \mathrm{L}^{-1}, 0.94 \pm 0.9 \mathrm{mg} . \mathrm{L}^{-1}, 3.0 \pm 1.4 \mathrm{mg} . \mathrm{L}^{-1}$, and $240.4 \pm 205.4 \mu \mathrm{g} . \mathrm{L}^{-1}$, respectively) were higher $(t>2.2$, $P<0.05$; Table 1) compared to the other three watersheds (mean for all watersheds: $1.83 \pm 0.8 \mathrm{mg} . \mathrm{L}^{-1}, 4.4 \pm$ $1.4 \mathrm{mg} . \mathrm{L}^{-1}, 0.31 \pm 0.44 \mathrm{mg} . \mathrm{L}^{-1}, 2.1 \pm 0.5 \mathrm{mg} . \mathrm{L}^{-1}$, and $41.4 \pm 40.8 \mu \mathrm{g} . \mathrm{L}^{-1}$, respectively). These results clearly signify strong anthropogenic effects on the ecosystem. A distinct feature observed in all the watersheds was that the inflow of tributaries/streams/rivers causes an influx in the nutrient levels (Fig. 2) in the subsequent sampling sites. In the Han River, Geum River, and Nakdong River watersheds, the confluence with the impacted tributaries is nearer the downstream of the watershed. However, in the Yeongsan River watershed, the confluence of the urbanimpacted Gwangju stream is in the upstream region (at around $50 \mathrm{~km}$ from the upstream of the watershed). Simultaneously, there is an influx of nutrients from the agricultural farms located on the land adjoining the lower half of the watershed, transforming it to a nutrient-rich system.

\section{Fish fauna and compositions}

In total, 23681 fishes belonging to 84 species were observed from the four major Korean watersheds (Table 2) and the numbers varied highly, depending on the location of the watershed. Fish fauna, based on CPUE 
revealed that four species such as Zacco platypus $(28.3 \%)$, Opsarichthys uncirostris amurensis (8.8\%), Acheilognathus yamatsutae (6.1\%), and Zacco koreanus (5.2\%) were major dominant fishes in Korea. Species abundance during 2008-2009 was highest (61 species) in Han River among the four watersheds and lowest (32 species) in Yeongsan River.

Longitudinal gradients of fish species compositions were evident in Han River watershed along the main axis of the river, resulting in distributional segregation of fish species (Fig. 3). The fish species observed in the upstream sites (Acheilognathus signifier Berg, Hemibarbus mylodon Berg, Z. koreanus, Pseudopungtungia tenuicorpa Jeon and Choi) were distinctly different from those observed in the downstream sites (Repomucenus olidus Gunther, Coilia nasus Temmnick and Schlegel, Synechogobius hasta Temmnick and Schlegel, Anguilla japonica Temmnick and Schlegel, Trachidermus fasciatus Heckel, Tridentiger bifasciatus Steindachner, Chelon haematocheilus Temmnick and Schlegel), suggesting a variation in the habitat structure coupled with water quality parameters in these sites. The Geum River and the Nakdong River watersheds exhibited intermediate levels of spatial species segregation between the upstream and downstream sites. This phenomenon was not observed in the Yeongsan River watershed.

Korean endemic species observed were 35, and this was $29.6 \%$ of the total in the Korean peninsula, which was slightly higher than the previous report $(22.5 \%)$ of Nam (1996). Analysis of endemic species fauna showed that relative abundances (RA) in two watersheds of Han River and Geum River was 33.3 and $32.9 \%$, respectively, and was two-fold greater than the abundance $(13.6 \%)$ of Yeongsan River watershed. Such differences were mainly attributed to habitat destruction and nutrient enrichment in the rivers. Our observation is supported by the previous report of Choi et al. (2000) who studied the relation between the number of endemic species and habitat quality.

Legally protected species viz., endangered species and natural monuments were composed of $1.2 \%$ (eight species) of the total. Among these, three were classified as first-class endangered species (Pseudopungtungia nigra Morim, Gobiobotia nakdongensis Mori, and Koreocobitis naktongensis Kim, Park and Nalbant) and four (P. tenuicorpa, Gobiobotia macrocephala Mori, A. signifer, and Gobiobotia brevibarba Mori) were classified as secondclass endangered species by MOE/NIER (2008). Only one natural monument was recorded in this study (Natural monument No. 259; H. mylodon), sampled in Han River watershed. This species was previously distributed in both the Han River and the Geum River watersheds, but became extinct in the Geum River watershed in the 1980s. Later, this species was artificially restored in Geum River watershed by the National Fisheries Research and Development Institute (NFRDI) in 1999. However, this species was not found in the Geum River watershed in our study.

Many exotic species, such as largemouth bass (Micropterus salmoides Lacepede), bluegill (Lepomis 

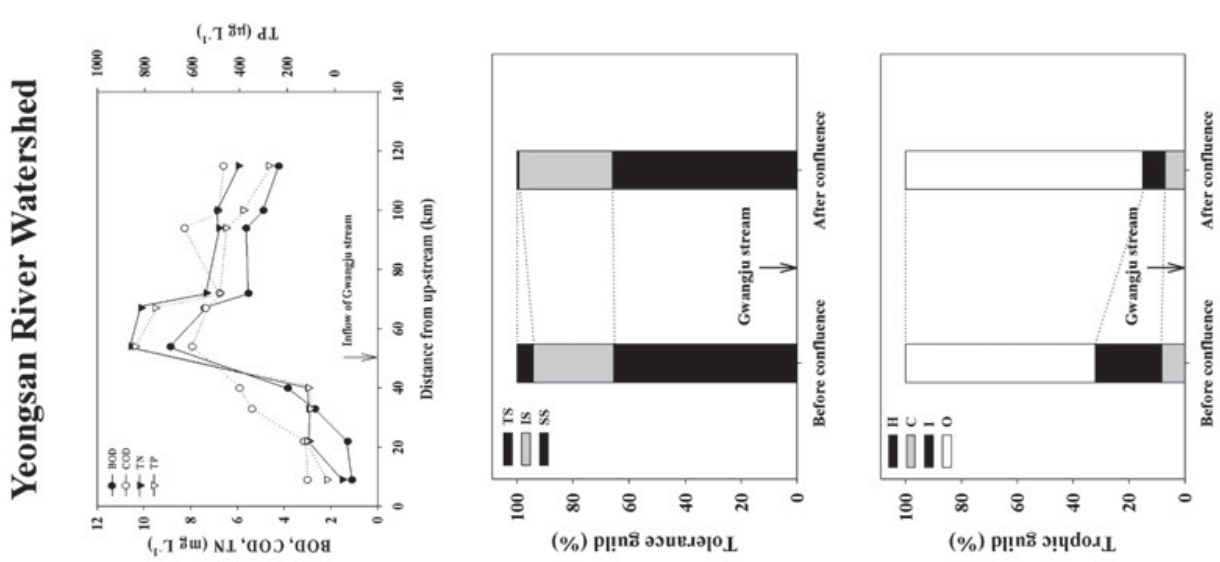

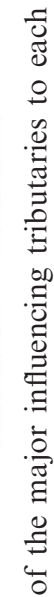
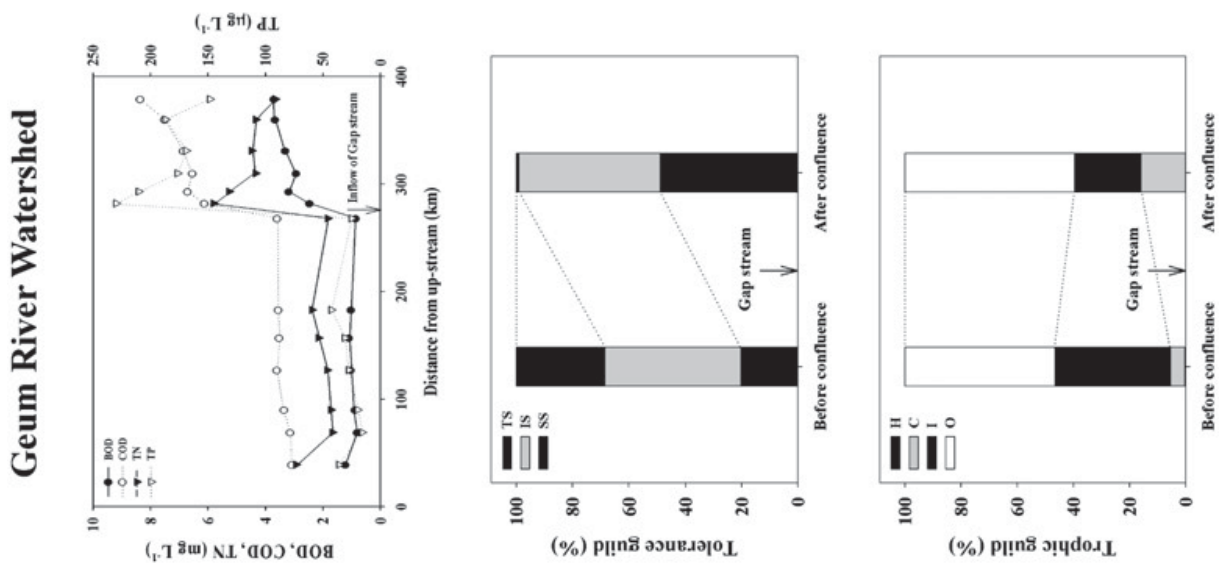

을
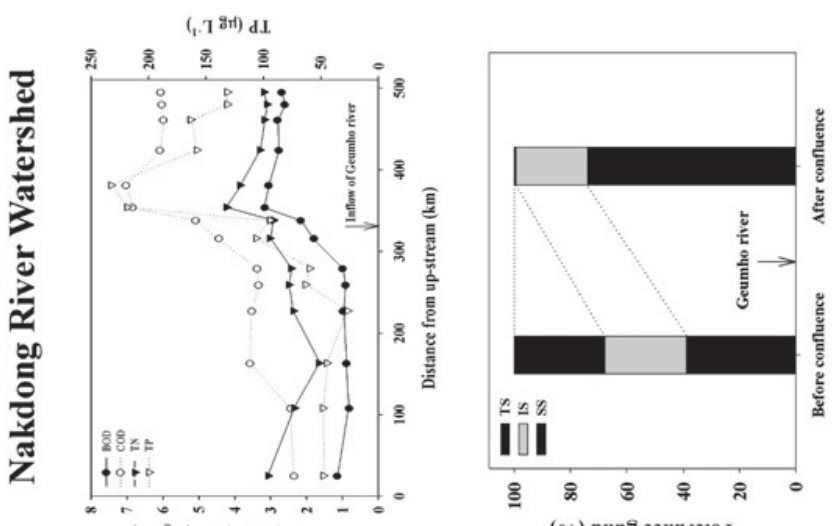

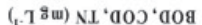

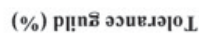
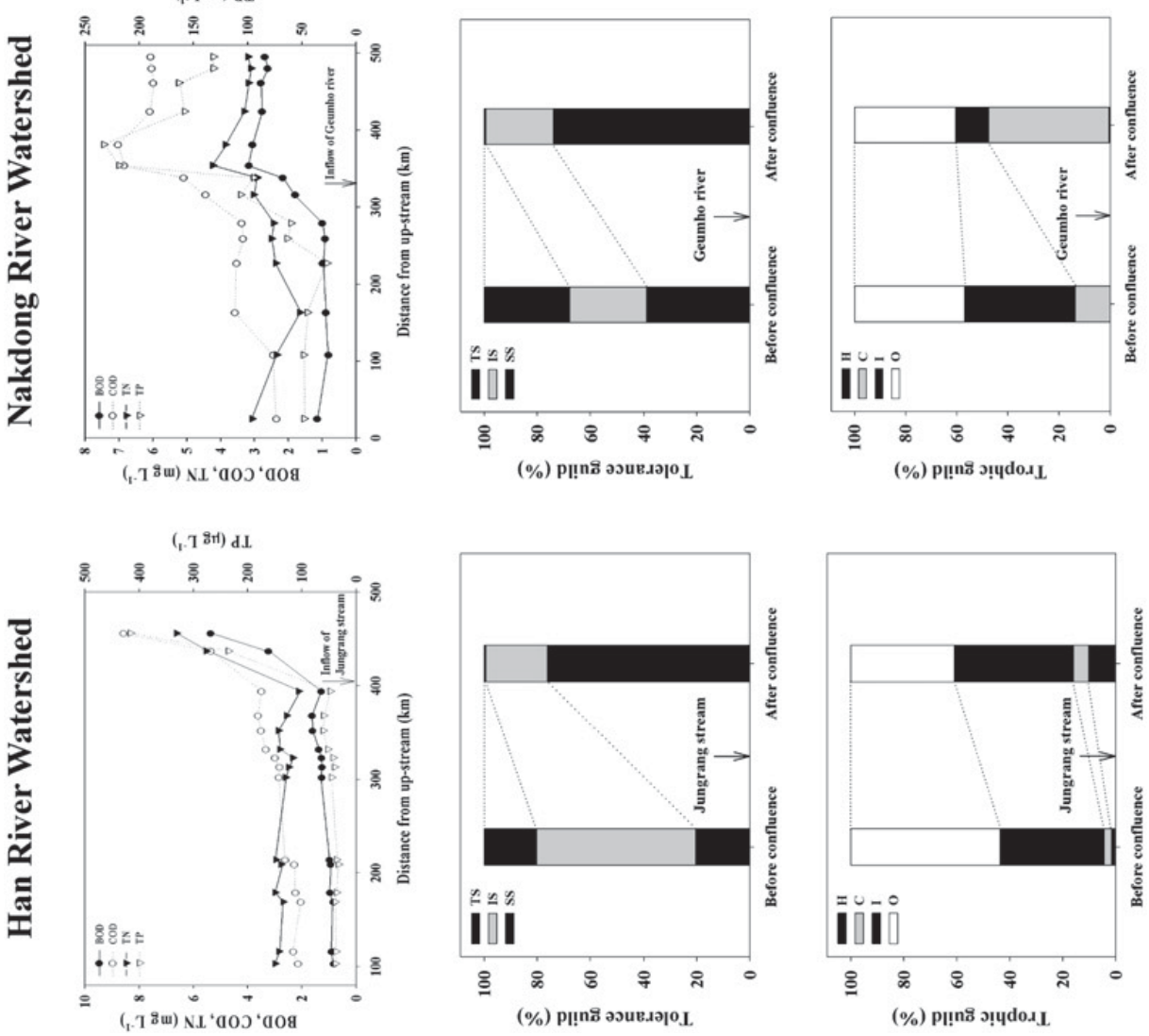

离

స

பั)

है

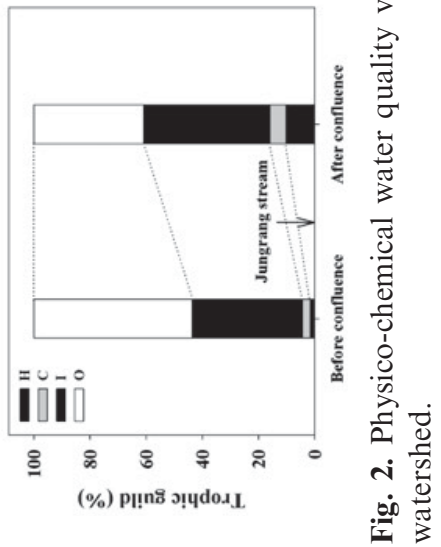



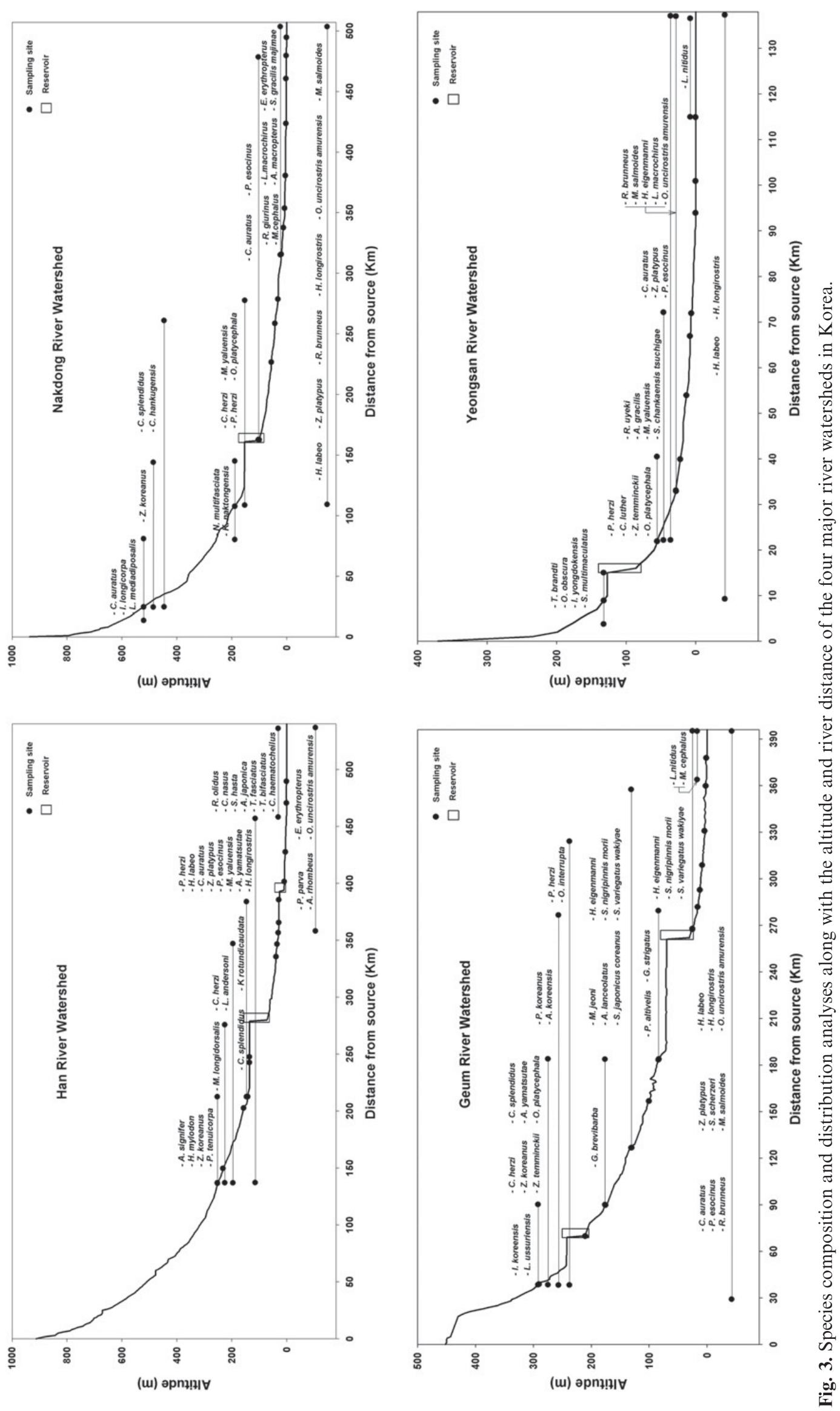
Table 2. Fish fauna and guild compositions in the four major Korean river watersheds.

\begin{tabular}{|c|c|c|c|c|c|c|c|c|c|}
\hline & \multirow[b]{2}{*}{ Species } & \multicolumn{3}{|c|}{ Guilds } & \multicolumn{4}{|c|}{ River watersheds } & \multirow[b]{2}{*}{ Total } \\
\hline & & Tolerance & Trophic & Habitat & $\overline{\text { Han }}$ & Nankdong & Geum & Yeongsan & \\
\hline & Zacco platypus & TS & $\mathrm{O}$ & & 2271 & 850 & 2323 & 1265 & 6709 \\
\hline & Opsarichthys uncirostris amurensis & TS & $\mathrm{C}$ & & 182 & 867 & 965 & 60 & 2074 \\
\hline Y & Acheilognathus yamatsutae & IS & $\mathrm{O}$ & & 1301 & & 148 & & 1449 \\
\hline Y & Zacco koreanus & SS & I & & 297 & 507 & 436 & & 1240 \\
\hline \multirow[t]{8}{*}{ Y } & Squalidus japonicus coreanus & TS & $\mathrm{O}$ & & 110 & & 763 & & 873 \\
\hline & Hemibarbus labeo & TS & $\mathrm{I}$ & & 317 & 93 & 356 & 99 & 865 \\
\hline & Pseudogobio esocinus & IS & I & & 203 & 105 & 437 & 63 & 808 \\
\hline & Rhinogobius brunneus & IS & I & $\mathrm{RB}$ & 409 & 101 & 218 & 1 & 729 \\
\hline & Zacco temminckii & SS & I & & & & 623 & 84 & 707 \\
\hline & Pungtungia herzi & IS & $\mathrm{I}$ & & 286 & 73 & 249 & 80 & 688 \\
\hline & Carassius auratus & TS & $\mathrm{O}$ & & 235 & 71 & 93 & 139 & 538 \\
\hline & Hemibarbus longirostris & IS & I & & 206 & 7 & 263 & 37 & 513 \\
\hline \multirow[t]{2}{*}{$¥$} & Micropterus salmoides & TS & $\mathrm{C}$ & & 62 & 155 & 59 & 197 & 473 \\
\hline & Tridentiger brevispinis & IS & I & $\mathrm{RB}$ & 138 & 24 & 302 & & 464 \\
\hline Y & Microphysogobio jeoni & IS & I & & 30 & & 400 & & 430 \\
\hline Y & Squalidus chankaensis tsuchigae & IS & $\mathrm{O}$ & & & 162 & 122 & 127 & 411 \\
\hline Y & Coreoleuciscus splendidus & SS & $\mathrm{I}$ & $\mathrm{RB}$ & 119 & 51 & 190 & & 360 \\
\hline \multirow[t]{2}{*}{ Y } & Acheilognathus koreensis & IS & $\mathrm{O}$ & & & & 323 & & 323 \\
\hline & Rhynchocypris oxycephalus & SS & I & & & 301 & & & 301 \\
\hline \multirow[t]{3}{*}{$\mathrm{Y}$} & Microphysogobio yaluensis & IS & $\mathrm{O}$ & $\mathrm{RB}$ & 71 & 11 & 83 & 103 & 268 \\
\hline & Hypomesus nipponensis & IS & I & & 240 & & & & 240 \\
\hline & Acheilognathus lanceolatus & IS & $\mathrm{O}$ & & 71 & & 163 & 3 & 237 \\
\hline Y & Squalidus gracilis majimae & SS & I & & 93 & 6 & 77 & & 176 \\
\hline Y & Odontobutis interrupta & IS & $\mathrm{C}$ & & 82 & & 61 & & 143 \\
\hline $\mathrm{Y}$ & Pseudopungtungia nigra* & SS & I & & & & 131 & & 131 \\
\hline Y & Coreoperca herzi & SS & $\mathrm{C}$ & & 33 & 22 & 71 & & 126 \\
\hline \multirow[t]{2}{*}{$\mathrm{Y}$} & Microphysogobio longidorsalis & SS & $\mathrm{H}$ & $\mathrm{RB}$ & 122 & & & & 122 \\
\hline & Squaliobarbus curriculus & IS & $\mathrm{O}$ & & & & 114 & & 114 \\
\hline \multirow[t]{5}{*}{ Y } & Pseudorasbora parva & IS & $\mathrm{O}$ & & 51 & 11 & 39 & 7 & 108 \\
\hline & Rhodeus uyekii & TS & $\mathrm{O}$ & & 77 & 1 & 11 & 19 & 108 \\
\hline & Acheilognathus rhombeus & IS & $\mathrm{O}$ & & 79 & 4 & 20 & 3 & 106 \\
\hline & Cyprinus carpio & TS & $\mathrm{O}$ & & 38 & 8 & 13 & 46 & 105 \\
\hline & Chaenogobius urotaenia & IS & I & & 94 & & 9 & & 103 \\
\hline Y & Odontobutis platycephala & SS & $\mathrm{C}$ & & & 9 & 86 & 3 & 98 \\
\hline Y & Iksookimia koreensis & IS & $\mathrm{I}$ & $\mathrm{RB}$ & 59 & & 38 & & 97 \\
\hline Y & Acanthorhodeus gracilis & IS & $\mathrm{O}$ & & 12 & 25 & 52 & 6 & 95 \\
\hline$¥$ & Lepomis macrochirus & TS & I & & & 44 & 2 & 44 & 90 \\
\hline \multirow[t]{3}{*}{$\mathrm{Y}$} & Sarcocheilichthys variegatus wakiyae & SS & I & & 9 & & 65 & & 74 \\
\hline & Erythroculter erythropterus & TS & $\mathrm{C}$ & & 13 & 7 & 47 & & 67 \\
\hline & Chelon haematocheilus & TS & $\mathrm{H}$ & & 61 & & & & 61 \\
\hline \multirow[t]{2}{*}{$\mathrm{Y}$} & Abbottina springeri & $\mathrm{TS}$ & $\mathrm{O}$ & & & & & 60 & 60 \\
\hline & Hemiculter eigenmanni & SS & $\mathrm{C}$ & & & 8 & 28 & 23 & 59 \\
\hline \multirow[t]{2}{*}{$\mathrm{Y}$} & Siniperca scherzeri & TS & $\mathrm{O}$ & & 5 & 4 & 50 & & 59 \\
\hline & Orthrias nudus & SS & $\mathrm{I}$ & $\mathrm{RB}$ & 49 & 8 & & & 57 \\
\hline Y & Sarcocheilichthys nigripinnis morii & IS & I & & 17 & & 33 & 2 & 52 \\
\hline Y & Hemibarbus mylodon* & SS & I & & 50 & & & & 50 \\
\hline Y & Iksookimia longicorpa & IS & $\mathrm{I}$ & & & 45 & & & 45 \\
\hline Y & Koreocobitis rotundicaudata & SS & $\mathrm{O}$ & $\mathrm{RB}$ & 40 & & & & 40 \\
\hline & Acanthorhodeus macropterus & IS & $\mathrm{O}$ & & & 24 & 13 & 2 & 39 \\
\hline & Hemiculter leucisculus & TS & $\mathrm{O}$ & & 38 & & & & 38 \\
\hline Y & Pseudobagrus koreanus & SS & I & $\mathrm{RB}$ & 11 & & 26 & 1 & 38 \\
\hline & Rhinogobius giurinus & TS & I & & 3 & 23 & 12 & & 3 \\
\hline Y & Pseudopungtungia tenuicorpa* & SS & I & & 37 & & & & 37 \\
\hline & Misgurnus anguillicaudatus & $\mathrm{TS}$ & $\mathrm{O}$ & & 6 & 5 & 25 & & 36 \\
\hline Y & Gobiobotia brevibarba* & SS & $\mathrm{I}$ & $\mathrm{RB}$ & 12 & & 19 & & 31 \\
\hline & Rhodeus notatus & IS & $\mathrm{O}$ & & 28 & & 2 & & 30 \\
\hline & Synechogobius hasta & TS & $\mathrm{I}$ & & 26 & & & & 26 \\
\hline & Misgurnus mizolepis & TS & $\mathrm{O}$ & & 6 & 1 & 15 & 2 & 24 \\
\hline & Tridentiger obscurus & TS & I & & & 23 & & & 23 \\
\hline $\mathrm{Y}$ & Gobiobotia macrocephala* & SS & I & $\mathrm{RB}$ & 18 & & 4 & & 2 \\
\hline
\end{tabular}


Table 2. (Continued.)

\begin{tabular}{|c|c|c|c|c|c|c|c|c|c|}
\hline & \multirow[b]{2}{*}{ Species } & \multicolumn{3}{|c|}{ Guilds } & \multicolumn{4}{|c|}{ River watersheds } & \multirow[b]{2}{*}{ Total } \\
\hline & & Tolerance & Trophic & Habitat & $\overline{\text { Han }}$ & Nankdong & Geum & Yeongsan & \\
\hline \multirow[t]{3}{*}{$\bar{¥}$} & Carassius cuvieri & TS & $\mathrm{O}$ & & 16 & & & 4 & 20 \\
\hline & Leiocassis nitidus & $\mathrm{TS}$ & I & & & & 2 & 18 & 20 \\
\hline & Gobiobotia nakdongensis* & TS & I & & & 19 & & & 19 \\
\hline \multirow[t]{6}{*}{ Y } & Pseudobagrus fulvidraco & SS & I & $\mathrm{RB}$ & 4 & 3 & 11 & 1 & 19 \\
\hline & Plecoglossus altivelis altivelis & IS & $\mathrm{H}$ & & & & 18 & & 18 \\
\hline & Abbottina rivularis & $\mathrm{TS}$ & $\mathrm{O}$ & & 17 & & & & 17 \\
\hline & Tridentiger bifasciatus & TS & I & & 16 & & & & 16 \\
\hline & Repomucenus olidus & $\mathrm{TS}$ & $\mathrm{I}$ & & 15 & & & & 15 \\
\hline & Cobitis lutheri & IS & I & & 1 & & & 13 & 14 \\
\hline \multirow[t]{7}{*}{ Y } & Cobitis hankugensis & IS & I & & & 12 & & & 12 \\
\hline & Mugil cephalus & TS & $\mathrm{C}$ & & & 9 & 2 & & 11 \\
\hline & Anguilla japonica & IS & $\mathrm{C}$ & & 4 & & & 7 & 11 \\
\hline & Silurus asotus & $\mathrm{TS}$ & $\mathrm{H}$ & & 7 & 1 & 3 & & 11 \\
\hline & Gnathopogon strigatus & IS & I & & 2 & & 6 & & 8 \\
\hline & Trachidermus fasciatus & $\mathrm{TS}$ & I & & 7 & & & & \\
\hline & Liobagrus andersoni & IS & I & & 7 & & & & \\
\hline \multirow[t]{3}{*}{$\mathrm{Y}$} & Leiocassis ussuriensis & SS & I & $\mathrm{RB}$ & & 4 & 3 & & 7 \\
\hline & Lateolabrax maculatus & IS & $\mathrm{C}$ & & 5 & & & & \\
\hline & Rhodeus ocellatus & IS & $\mathrm{O}$ & & & & & 4 & 4 \\
\hline Y & Coilia nasus & SS & $\mathrm{O}$ & $\mathrm{RB}$ & 3 & & & & 3 \\
\hline $\mathrm{Y}$ & Koreocobitis naktongensis* & IS & $\mathrm{C}$ & & & 3 & & & 3 \\
\hline Y & Liobagrus mediadiposalis & SS & I & $\mathrm{RB}$ & & 3 & & & \\
\hline Y & Acheilognathus signifier* & SS & $\mathrm{O}$ & & 2 & & & & \\
\hline $\mathrm{Y}$ & Niwaella multifasciata & SS & $\mathrm{O}$ & $\mathrm{RB}$ & & 1 & & & \\
\hline \multicolumn{5}{|c|}{ Total number of species } & 61 & 43 & 54 & 32 & 84 \\
\hline \multicolumn{5}{|c|}{ Total number of individuals } & 7823 & 3711 & 9624 & 2523 & 23681 \\
\hline
\end{tabular}

Y: Korean endemic species, ¥: exotic species, *: legally protected species (endangered or natural monument), SS = sensitive species, $\mathrm{IS}=$ intermediate species, TS $=$ tolerant species, $\mathrm{O}=$ omnivores, $\mathrm{I}=$ insectivores, $\mathrm{C}=$ carnivores, $\mathrm{H}=$ herbivores, $\mathrm{RB}=$ riffle benthic species.

Table 3. Physical habitat evaluation using the QHEI in the four major river watersheds in Korea.

\begin{tabular}{|c|c|c|c|c|c|}
\hline \multirow{2}{*}{\multicolumn{2}{|c|}{ Habitat variables }} & \multicolumn{4}{|c|}{ River watersheds } \\
\hline & & \multirow{2}{*}{$\begin{array}{l}\text { Han } \\
8.8\end{array}$} & \multirow{2}{*}{$\begin{array}{l}\text { Nakdong } \\
8.9\end{array}$} & \multirow{2}{*}{$\begin{array}{l}\text { Geum } \\
12.9\end{array}$} & \multirow{2}{*}{$\frac{\text { Yeongsan }}{7.8}$} \\
\hline$\overline{\mathrm{M} 1}$ & Epifaunal substrate/Available cover & & & & \\
\hline \multirow[t]{2}{*}{ M2 } & $\left(\leq 3^{\mathrm{so}}\right)$ Embeddedness & & & & 8.1 \\
\hline & $\left(\geq 4^{\mathrm{so}}\right)$ Pool substrate characterization & 12.6 & 9.9 & 13.6 & 8.0 \\
\hline M3 & Channel flow status & 13.8 & 13.0 & 15.7 & 9.5 \\
\hline M4 & Existence of small-scale dams & 15.2 & 13.2 & 12.5 & 8.0 \\
\hline M5 & Channel alteration & 12.3 & 11.1 & 11.3 & 8.0 \\
\hline M6 & Sediment deposition & 14.4 & 12.1 & 14.9 & 8.2 \\
\hline \multicolumn{2}{|c|}{ Mean values of the QHEI (criteria of US EPA) } & $77.1(\mathrm{~B})^{*}$ & $68.1(\mathrm{~B})$ & $80.9(\mathrm{~B})$ & $49.4(\mathrm{C})$ \\
\hline
\end{tabular}

* B: good condition, $\mathrm{C}$ : fair condition, ${ }^{\mathrm{SO}}$ : stream order.

macrochirus Rafinesque), and Japanese crucian carp (Carassius cuvieri Temmnick and Schlegel), were widely distributed throughout these Korean watersheds. Largemouth bass, a well-known, notorious top predator that modifies fish species composition and disturbs trophic structures by indiscreet dietary activities (Maezono and Miyashita, 2004), was observed in all the four major watersheds (Choi et al., 2011); this species could cause major ecological disturbance, as predicted by the US EPA (1993). Thus, it is necessary to monitor these species continuously and study further to configure distributions and variation trends for intensive management of the lotic ecosystems.

\section{Guilds analyses}

Tolerance guild analysis showed that tolerant species dominated the lotic ecosystems we studied. The tolerant species constituted 52.4\% (12403 individuals; Table 2), while the sensitive species represented only $15.6 \%$ (3704 individuals) of the RA. The intermediate species 
K-IBIF vs. Water Quality Factor
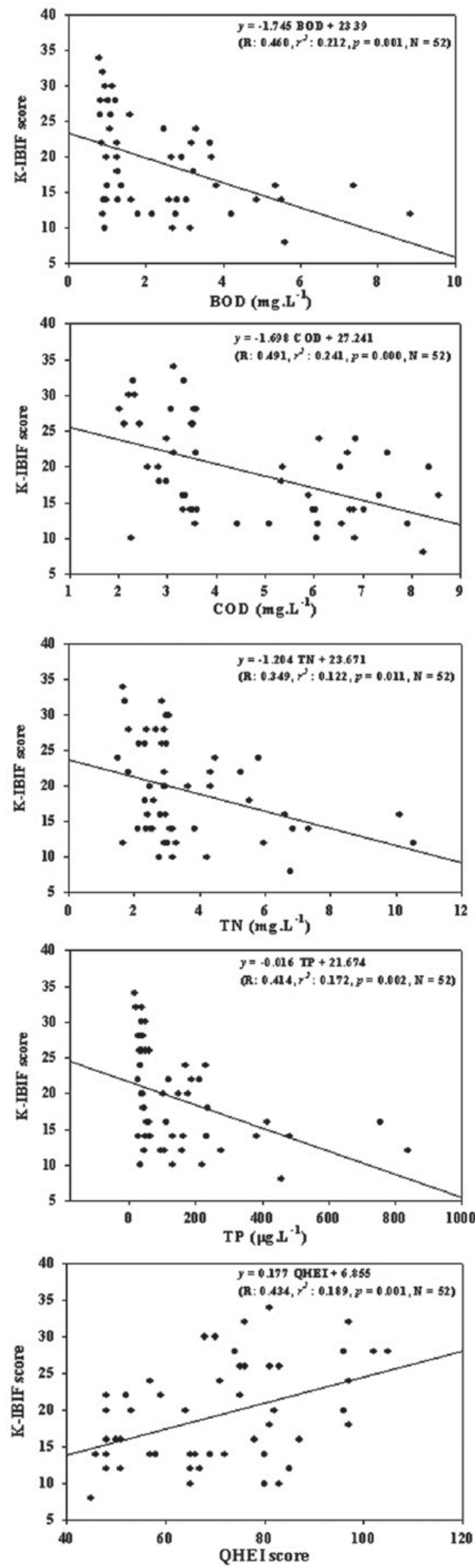

QHEI vs. Water Quality Factor
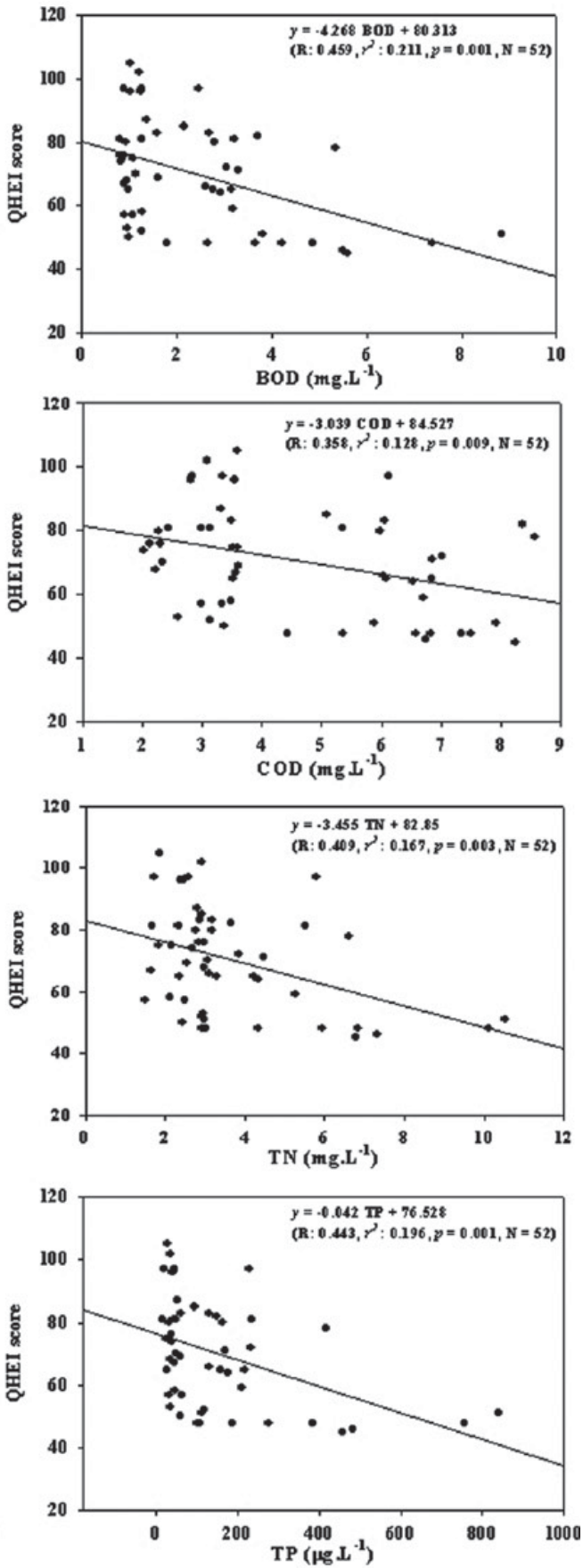

Fig. 4. Regression analyses of K-IBIF and QHEI values related to physico-chemical water quality parameters. 
constituted $32 \%$ (7574 individuals) of the RA. Trophic guild analysis also confirmed that the fish reflected the water quality of the system. The omnivores dominated the ecosystem. The proportion of omnivore species, as a number of individuals, was $49.9 \%$ (11 817 individuals), and in contrast, insectivore species was $36.2 \% \quad(8582$ individuals). The proportion of the carnivore species was $13 \%$ (3070 individuals), while others (such as herbivores and filter feeders) constituted $0.9 \%$. The ecological distribution of the tolerance and the trophic guilds was associated with the water quality parameters. Sensitive and insectivorous species rapidly decreased $(r<-0.42$, $P<0.01, n=52$ ) with degradation in water quality (BOD); while tolerant and omnivorous species dominated the system $(r>0.27, P<0.05, n=52)$.

The influx of nutrients via the watersheds into the tributaries/streams/rivers was observed to alter the dynamics of the guild structure (Fig. 2). RA of the sensitive species after the confluence was $<1 \%$ (previously $20-34 \%$ in Han, Geum, Nakdong River watersheds). Similar results were observed for insectivorous species after the confluence (13-22\% from $28-40 \%)$. The RA of the tolerant species shifted from $20-40 \%$ to $50-78 \%$. The Yeongsan River watershed did not show major guild alterations because the system was already nutrient rich as a result of the influx from the agricultural farms located on the land adjoining the lower half of the watershed. Our results are in accordance with the typical trend observed in eutrophic waters (Drake and Pereira, 2002). With an increase in pollution, sensitive species and insectivores are eliminated from the guild structure, paving the way for the emergence of an omnivorous population (US EPA, 1998; Barbour et al., 1999).

\section{Physical habitat health evaluation}

Physical habitat health, based on a QHEI model, evaluated for the four major watersheds in Korea indicated a "good" condition (mean QHEI 68.9, range $45-105, n=52$; Table 3) during the study period. This wide range of QHEI values indicates that fish cannot survive in some streams as a result of habitat degradation. Most of this degradation was caused by habitat modification, artificial channelization, and weir and bank construction, which disturb the habitat. The QHEI scores clearly correlated with the nutrient levels $\left(R^{2}>0.4, P<0.01\right.$; Fig. 4) in all the major watersheds. Our results reveal that the three of the major watersheds, Han River, Geum River, and Nakdong River watersheds exhibited "good" QHEI scores (mean 75.37), but also displayed a linear degradation of habitat toward the downstream. However, the QHEI scores in the Yeongsan River watershed (mean 49.4) was considerably lower $(t<-4.3, \quad P<0.001)$, pointing to the need for a restoration of habitat in this watershed. In this study, most of the degraded sites were caused by habitat modification along with artificial channelization, and weir and bank construction, all associated with human activities. Consequently, these effects cause aquatic habitat disturbance, fish community modifications, and finally lower the biological health of the ecosystem. Our results suggest that physical habitat quality influences the guild structure in fish community and is closely associated with IBI values as proposed by Plafkin et al. (1989).

\section{Biological integrity}

The model values of K-IBIF during 2008-2009 averaged 18.2, which was judged as a "fair" condition by the ecological health criteria of US EPA (1993). The values, however, varied highly between 8 and 34 in the watersheds depending on the location. None of the study sites, however, could be judged as in an "excellent" condition. According to the national health assessments of 52 rivers, $25 \%$ of the total was judged as "good" condition, while $36.5 \%$ was a "poor", indicating a severe impaired ecological health.

The ecological health of Yeongsan River watershed (mean K-IBIF 14.4; "poor") was lower $(t<-3.9$, $P<0.006$ ) than all the other three watersheds (mean K-IBIF: Geum 20.7, "Fair"; Han 20.4, "Fair"; Nakdong 17.1, "Fair") (Table 4). The lower scores in the Yeongsan River watershed can be attributed to the influx of high nutrient into the rivers and the disturbance of habitat in the system (Table 5). As a result, the total number of species observed in this watershed $(12 \pm 2.8)$ was comparatively lower $(t<-4.62, P<0.001)$ than the other watersheds (Mean: $19.0 \pm 3.6$ ). These results are consistent with previous reports on this watershed (Choi and An, 2007), which show a dominance of tolerant and omnivore species, exotics, and fishes with DELT anomalies, thus indicating a severe deterioration of the system. Simultaneously, the values of BOD, TP, and TN were all negatively correlated with the biological variables of the K-IBIF model $(r<-0.34, P<0.05$; Fig. 3$)$, and positively correlated with the QHEI scores $(r=0.43, P<0.01)$. Here, physical habitat and the chemical health seem to be important factors regulating the biological health of the system.

Cluster analysis, based on 52 sampling sites sampled during 2008-2009, showed that the river sites were divided into two groups of Group-I (19 sites: H01-H05 from top to bottom) and Group-II (43 sites: H10-Y10 from top to bottom) (Fig. 5). The results revealed that the K-IBIF values were directly influenced by spatial variations, chemical conditions, and physical habitat quality. When we analyzed the ecological characteristics of Group-I, the river sites were mainly located in the zone of headwaterto-upstream sites where the rivers are in the range of first-third order and ecological river health is mainly judged as good conditions. In contrast, characteristics of Group-II, the river sites were mainly located in the zone of midstream-to-downriver sites (Fig. 5) where the rivers are in the range of third-sixth order and the ecological river health was mainly judged as poor conditions. Statistical unpaired $t$-tests between the two groups, based 
Table 4. Summary of the K-IBIF model in the four major river watersheds in Korea.

\begin{tabular}{|c|c|c|c|c|c|c|}
\hline \multirow[b]{2}{*}{ Metric attributes } & \multirow{2}{*}{\multicolumn{2}{|c|}{ Metric components }} & \multicolumn{4}{|c|}{ River watersheds } \\
\hline & & & Han & Nakdong & Geum & Yeongsan \\
\hline \multirow[t]{3}{*}{ I. Species composition } & M1 & Total number of native species & 2.2 & 1.2 & 3.0 & 2.8 \\
\hline & M2 & Number of sensitive species & 1.7 & 1.0 & 1.5 & 1.0 \\
\hline & M3 & Tolerant species as percent individuals & 1.5 & 1.1 & 2.0 & 1.3 \\
\hline \multirow[t]{2}{*}{ II. Trophic composition } & M4 & Omnivores as percent individuals & 2.4 & 2.4 & 1.5 & 1.2 \\
\hline & M5 & Insectivores as percent individuals & 3.1 & 3.4 & 2.3 & 1.4 \\
\hline \multirow[t]{3}{*}{ III. Abundance and individual health } & M6 & Total number of individuals & 3.9 & 2.0 & 3.6 & 1.6 \\
\hline & M7 & Exotic species as percent individuals & 1.1 & 1.1 & 2.2 & 1.8 \\
\hline & M8 & Anomalies as percent individuals & 4.7 & 4.9 & 4.6 & 3.5 \\
\hline Score of K-IBIF model (criteria) & & & $20.4(\mathrm{C})^{*}$ & $17.1(\mathrm{C})$ & $20.7(\mathrm{C})$ & $14.4(\mathrm{D})$ \\
\hline
\end{tabular}

* C: fair condition; D: poor condition.

Table 5. Spearman's rank order correlations between the K-IBIF and environmental variables and HBI in each of the four major river watersheds.

\begin{tabular}{|c|c|c|c|c|c|}
\hline \multirow{2}{*}{\multicolumn{2}{|c|}{ Environmental variables }} & \multicolumn{4}{|c|}{ River watershed } \\
\hline & & Han & Geum & Nankdong & $\overline{\text { Yeongsan }}$ \\
\hline \multirow[t]{3}{*}{ Physical } & Water temperature & -0.183 & -0.001 & -0.412 & -0.611 \\
\hline & SS & -0.083 & $-0.688 *$ & -0.355 & $-0.807^{*}$ \\
\hline & Conductivity & 0.158 & $-0.822 *$ & 0.127 & $-0.819 *$ \\
\hline \multirow[t]{7}{*}{ Chemical } & BOD & -0.054 & $-0.710 *$ & -0.453 & $-0.758 *$ \\
\hline & COD & $-0.546^{*}$ & $-0.805^{*}$ & $-0.665^{*}$ & $-0.844^{*}$ \\
\hline & $\mathrm{TN}$ & 0.318 & $-0.618 *$ & -0.396 & $-0.661 *$ \\
\hline & TP & -0.351 & $-0.646^{*}$ & -0.398 & $-0.673^{*}$ \\
\hline & $\mathrm{NH}_{3}-\mathrm{N}$ & -0.291 & $-0.735^{*}$ & -0.457 & $-0.716^{*}$ \\
\hline & $\mathrm{NO}_{3}-\mathrm{N}$ & 0.396 & $-0.563 *$ & -0.196 & -0.606 \\
\hline & $\mathrm{PO}_{4}-\mathrm{P}$ & -0.318 & $-0.643^{*}$ & $-0.592 *$ & $-0.654^{*}$ \\
\hline Habitat quality & QHEI & -0.107 & $0.607 *$ & -0.021 & $0.668 *$ \\
\hline
\end{tabular}

$* P<0.05$.

on dataset of multi-metric model values of K-IBIF and QHEI, showed that Group-I was significantly greater $(P<0.05)$ than the Group-II. Also, $t$-tests between the two groups, based on chemical nutrient data (TP), revealed that Group-I was significantly lower $(P<0.05)$ than the Group-II. These results suggest that habitat segregation in the fish community of two groups may be attributed to combined effects of physical habitat and water quality. Thus, such physical and chemical differences between the two groups resulted in different types of fish community.

In addition, we used an ordination approach using PCA to elucidate some relations between the ecological health (K-IBIF) and some physico-chemical factors (Fig. 6). The ordination approach has an advantage (Braak, 1987; Legendre and Legendre, 1998) that similar sites plot are closer to one another, and dissimilar sites plot are farther apart. In our PCA analysis, the axes I, II, and III together accounted for $74.3 \%$ of the variance as shown in Table 6. The axis-I explained $47.1 \%$ of the variance based on criteria of factor loading $\geq|0.30|$ determined by organic matters (BOD, COD), nutrients (TN, TP), and water temperature, while the axis-II explained $18.4 \%$ of the variance by physical habitat of QHEI and its three metrics. The axis-III is explained by $8.8 \%$ variances determined by one water quality parameter (conductivity) and three QHEI metrics against the criteria of factor loading $\geq|0.30|$. It is thus evident that the nutrients as well as organic matters reflected by BOD and COD in the watersheds have an influence on the biological integrity, and especially, the downstream sites (K-IBIF 8-16) were clearly associated with high nutrient levels. Incidentally, all the upstream sites are located where there is a higher proportion of forest cover. These results indicate that downstream sites suffer from large-scale habitat disturbance, and water pollution. Therefore, land-use patterns surrounding the sampling sites are an important factor to be considered for the development of restoration strategies and management programs.

\section{Conclusions}

Our national-level biomonitoring of the four major watersheds in Korea revealed that all the watersheds were primarily impacted by high nutrient levels (both TP and 


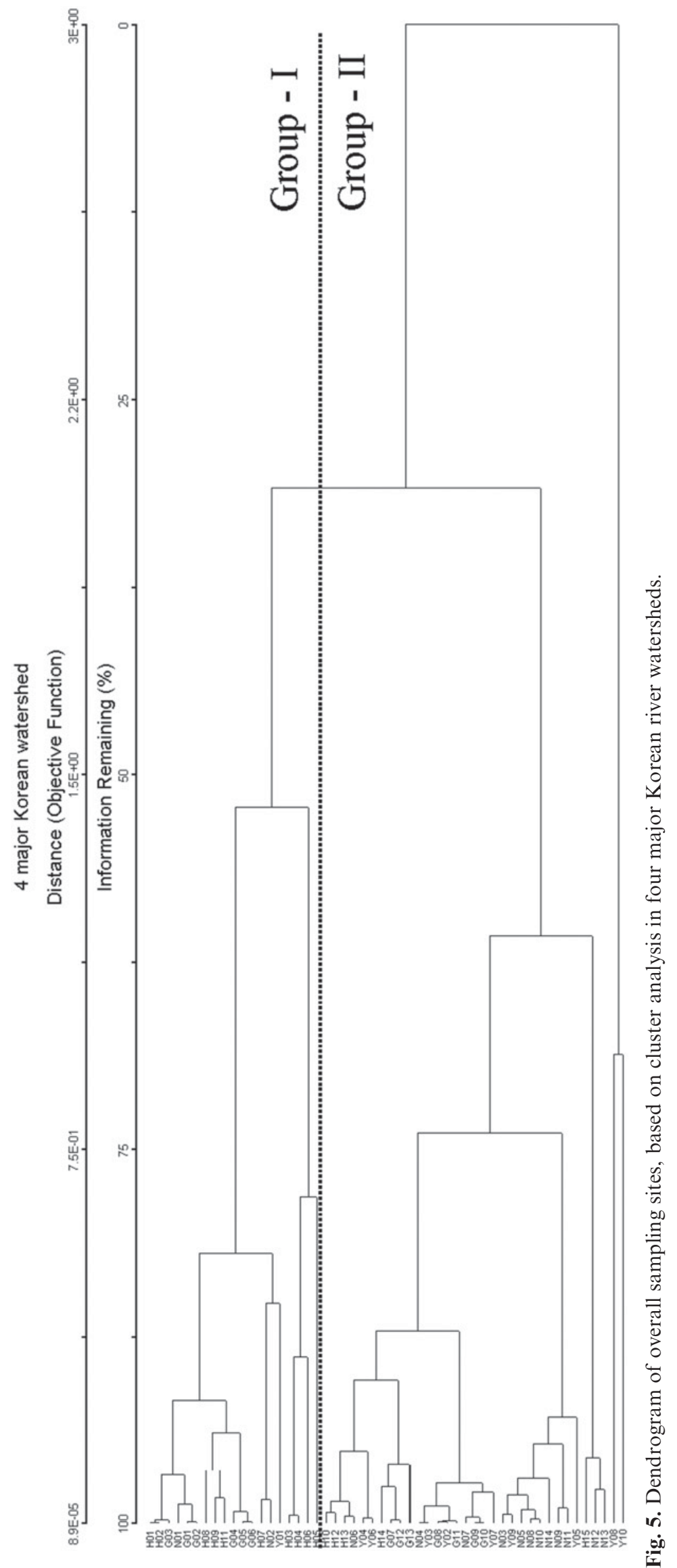


Table 6. PCA using physico-chemical variables. The data were loaded on axes I, II, and III and the values indicate correlation coefficients. Bold numbers were expressed as high significant values of $\geq|0.30|(P<0.05)$.

\begin{tabular}{|c|c|c|c|c|}
\hline \multirow[b]{2}{*}{ Variables } & & \multicolumn{3}{|c|}{ Axes } \\
\hline & & $\mathrm{I}$ & II & III \\
\hline \multirow[t]{4}{*}{ Chemical } & BOD & 0.3516 & -0.2062 & 0.1163 \\
\hline & COD & 0.3234 & -0.2714 & -0.0776 \\
\hline & $\mathrm{TN}$ & 0.3206 & -0.1937 & 0.192 \\
\hline & $\mathrm{TP}$ & 0.3337 & -0.1812 & 0.1968 \\
\hline \multirow[t]{3}{*}{ Physical } & Temperature & 0.3017 & -0.1382 & 0.284 \\
\hline & Conductivity & 0.1953 & -0.2862 & -0.3073 \\
\hline & Chlorophyll- $a$ & 0.2691 & -0.2388 & -0.1366 \\
\hline \multirow[t]{6}{*}{ Metric of QHEI } & H-M1 & -0.2151 & -0.1747 & 0.5389 \\
\hline & H-M2 & -0.2662 & -0.1301 & 0.3799 \\
\hline & $\mathrm{H}-\mathrm{M} 3$ & -0.1656 & -0.3764 & -0.2722 \\
\hline & H-M4 & -0.2196 & -0.3697 & -0.0827 \\
\hline & H-M5 & -0.191 & -0.3477 & 0.1494 \\
\hline & H-M6 & -0.1959 & -0.2349 & -0.4046 \\
\hline Habitat quality & QHEI & -0.2974 & -0.3918 & 0.097 \\
\hline Eigenvalue & & 6.594 & 2.579 & 1.234 \\
\hline Proportion of variance & & 47.101 & 18.421 & 8.814 \\
\hline Cumulative proportion & & 47.101 & 65.522 & 74.336 \\
\hline
\end{tabular}

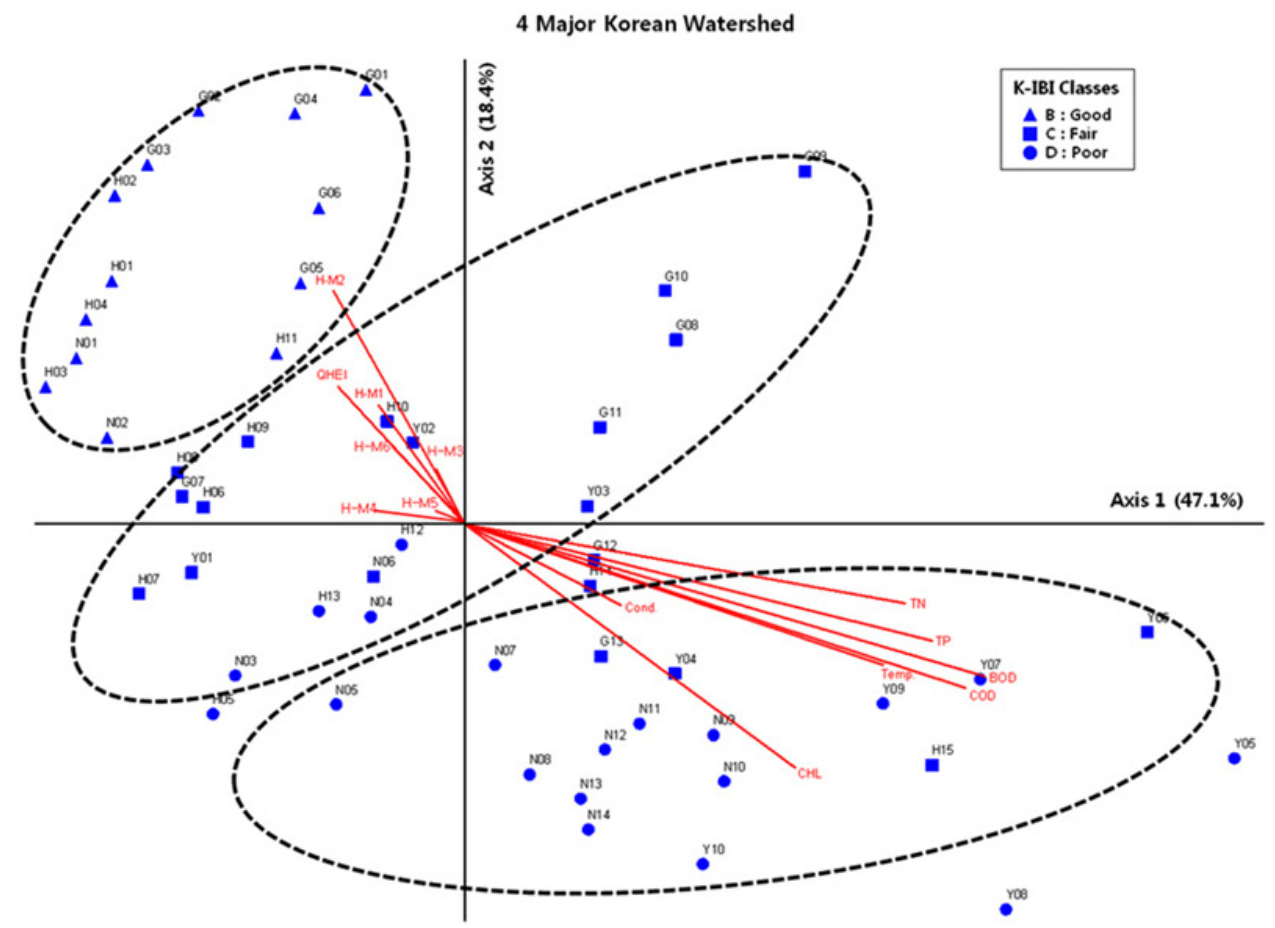

Fig. 6. PCA of the four major Korean river watersheds, based on physical habitat, chemical conditions, and biological components.

TN) along with anthropogenic disturbance of physical habitat. Among the four watersheds, Yeongsan River was in the most deteriorated condition with very high levels of nutrients and organic matters, and also severe habitat degradation. All the other watersheds displayed a linear degradation of habitat toward the downstream, pointing to the need for restoration.
Fish fauna and compositions showed a high abundance in Han River watershed (61 species) whereas they were in low abundance in Yeongsan River along with low abundance of the Korean endemic species. Fish trophic and tolerance guild analysis revealed that tolerant and omnivorous species dominated all the watersheds; the sensitive and insectivorous species rapidly decreased 
with a degradation of water quality. Our studies also revealed that three major exotic species, largemouth bass (M. salmoides), bluegill (L. macrochirus) and Japanese crucian carp (C. cuvieri), were widely distributed in all the major watersheds, and need to be continuously monitored because these can alter the guild structure and cause ecological disturbances. The ecological health (K-IBIF values) in all the watersheds deteriorated post-confluence with impacted tributaries.

Overall, our survey results suggest that biological integrity in Korean rivers is in a marginal to poor condition. The downriver sites in the watersheds suffer from large-scale habitat disturbance by various river channel constructions and water contamination as a result of urban impacts and industrial development. In our health assessments, wastewater effluents from urban regions were the major source of nutrient and organic pollutions, influencing the ecological health in the end. We believe that this research provides key information such as physical habitat quality, chemical water quality, and biological health, required the river restoration strategies and efficient river management in the future.

Acknowledgements. This study was financially supported by the Ministry of Environment and the National Institute of Environmental Research (Korea), and the results of this study form part of the "Survey and Evaluation of Aquatic Ecosystem Health in Korea, 2009”. The authors would like to thank all survey members involved in the project, for their help in the samplings and analyses. We also thank reviewers for their constructive comments in improving the manuscript.

\section{References}

An K.-G. and Lee E.H., 2006. Ecological health assessments of Yoogu Stream using a fish community metric model. Korean J. Limnol., 39, 310-319 (in Korean with English summary).

An K.-G., Jung S.H. and Choi S.S., 2001a. An evaluation on health conditions of Pyong-Chang River using the index of biological integrity (IBI) and qualitative habitat evaluation index (QHEI). Korean J. Limnol., 34, 153-165 (in Korean with English summary).

An K.-G., Yeom D.H. and Lee S.K., 2001b. Rapid bioassessments of Kap Stream using the index of biological integrity. Korean J. Environ. Biol., 19, 216-269 (in Korean with English summary).

An K.-G., Kim D.S., Kong D.S. and Kim S.D., 2004. Integrative assessments of a temperate stream based on a multimetric determination of biological integrity, physical habitat evaluations, and toxicity tests. Bull. Environ. Contam. Toxicol., 73, 471-478.

An K.-G., Lee J.Y., Bae D.Y., Kim J.H., Hwang S.J., Won D.H., Lee J.K. and Kim C.S., 2006. Ecological assessments of aquatic environment using multi-metric model in major nationwide stream watersheds. J. Korean Water Qual., 22, 796-804 (in Korean with English summary).

APHA, 2005. Standard Methods for the Examination of Water and Waste Water, 21st edn., American Public Health Association, New York, NY.
Bae D.Y. and An K.-G., 2006. Stream ecosystem assessments, based on a biological multimetric parameter model and water chemistry analysis. Korean J. Limnol., 39, 198-208 (in Korean with English summary).

Barbour M.T., Gerritsen J., Snyder B.D. and Stribling J.B., 1999. Rapid Bioassessment Protocols for Use in Streams and Wadeable Rivers: Periphyton, Benthic Macroinvertebrates and Fish, 2nd edn., EPA 841-B-99-002, Office of Water, US EPA, Washington, DC.

Binns N.A. and Eiserman F.M., 1979. Quantification of fluvial trout habitat in Wyoming. T. Am. Fish. Soc., 108, 215-228.

Boon P.J., 2000. The development of integrated methods for assessing river conservation value. Hydrobiologia, 422, 413-428.

Braak C.J.F., 1987. The analysis of vegetation-environment relationships by canonical correspondence analysis. Vegetation, 69, 69-77.

Brookes A. and Shields F.D. Jr., 1996. River Channel Restoration: Guiding Principles for Sustainable Projects, Wiley, Chichester, 433 p.

Choi J.K., Byeon H.K. and Seok H.K., 2000. Studies on the dynamics of fish community in Wonju Stream. Korean $J$. Limnol., 33, 274-281 (in Korean with English summary).

Choi J.W. and An K.-G., 2007. Fish composition and trophic guild analysis as a collection of basic data for ecosystem health assessments in Yeongsan Lake. Korean J. Limnol., 40, 546-552 (in Korean with English summary).

Choi J.W., Kumar H.K., Han J.H. and An K.-G., 2011. The development of a regional multimetric fish model based on biological integrity in lotic ecosystems and some factors influencing the stream health. Water Air Soil Pollut., 217, 3-24.

Crumpton W.G., Isenhart T.M. and Mitchell P.D., 1992. Nitrate and organic $\mathrm{N}$ analyses with second-derivative spectroscopy. Limnol. Oceanogr., 37, 907-913.

Desirree D.T., David L.P. and Gregory D.J., 2006. Development and application of a bioindicator for benthic habitat enhancement in the North Carolina Piedmont. Ecol. Eng., 27, 228-241.

DIN 38410, 1990. Biological-ecological analysis of water (group M); determination of the saprobic index (M2). German standard methods for the examination of water, Part 2, Waste water and sludge, $10 \mathrm{p}$.

Drake M.T. and Pereira D.L., 2002. Development of a fish-based index of biotic integrity for small inland lakes in Central Minnesota. N. Am. J. Fish. Manage., 22, 1105-1123.

European Commission, 2000. Directive 2000/60/EC of the European Parliament and of the Council establishing a framework for Community action in the field of water policy. Official Journal, L327, 72 p.

Fore L.S., Karr J.R. and Conquest L.L., 1993. Statistical properties of an index of biological integrity used to evaluate water resources. Can. J. Fish. Aquat. Sci., 51, 1077-1087.

Gore J.A., 1985. The Restoration of Rivers and Streams, Butterworth, Stoneham, 280 p.

Han J.H., Bae D.Y. and An K.-G., 2007. Ecosystem health assessments of Changwon Stream as a preliminary diagnosis for aquatic ecosystem restoration. Korean J. Limnol., 40, $527-536$.

Hughes R.M., Heiskary S.A., Mathews W.J. and Yoder C.O., 1994. Use of ecoregions in biological monitoring. In: Loeb S.L. and Spacie A. (eds.), Biological Monitoring of Aquatic Systems, Lewis, Chelsea, 125-151. 
Hugueny B.S., Camara B., Samoura B. and Magassouba M., 1996. Applying an index of biotic integrity based on communities in a West African river. Hydrobiologia, 331, 71-78.

Hwang S.J., Kim N.Y., Won D.H., An K.-G., Lee J.K. and Kim C.S., 2006. Biological assessment of water quality by using epilithic diatoms in major river systems (Geum, Youngsan, Seomjin River). J. Korean Water Qual., 22, 784-795 (in Korean with English summary).

Karr J.R., 1981. Assessment of biotic integrity using fish communities. Fisheries, 6, 21-27.

Karr J.R. and Dionne M., 1991. Designing surveys to assess biological integrity in lakes and reservoirs. In: Biological Criteria Research and Regulation-Proceedings of a Symposium, EP-440/5-91-005, US EPA, Office of Waters, Washington, DC, 62-72.

Karr J.R., Heidinger R.C. and Helmer E.H., 1985a. Effects of chlorine and ammonia from wastewater treatment facilities on biotic integrity. J. Water Pollut. Con. F., 57, 912-915.

Karr J.R., Toth L.A. and Dudley D.R., 1985b. Fish communities of midwestern rivers: a history of degradation. BioScience, $35,90-95$.

Karr J.R., Fausch K.D., Angermeier P.L., Yant P.R. and Schlosser I.J., 1986. Assessment of biological integrity in running waters: a method and its rationale, Special publication 5, Illinois Natural History Survey, Champaign, IL, 28 p.

Kelly M.G., Cazaubon A., Coring E., Dell'Uomo A., Ector L., Goldsmith B., Guasch H., Hurlimann J., Jarlman A., Kawecka B., Kwandrans J., Laugaste R., Lindstrom E.-A., Leitao M., Marvan P., Padisak J., Pipp E., Prygiel J., Rott E., Sabater S., van Dam H. and Vizinet J., 1998. Recommendations for the routine sampling of diatoms for water quality assessments in Europe. J. Phycol., 10, 215-224.

Kelly M.G. and Whitton B.A., 1995. The trophic diatom index: a new index for monitoring eutrophication in rivers. J. Appl. Phycol., 7, 433-444.

Kim I.S. and Park J.Y., 2002. Freshwater fishes of Korea, Kyohaksa, Seoul, 465 p. (in Korean).

Kleynhans C.J., 1999. The development of a fish index to assess the biological integrity of South African rivers. Water $S A, 25$, 265-278.

Koizumi N. and Matsumiya Y., 1997. Assessment of stream fish habitat based on index of biotic integrity. Bull. Jpn. Soc. Fish. Oceanogr., 61, 144-156.

Kwon Y.S. and An K.-G., 2006. Biological stream health and physico-chemical characteristics in the Keum-Ho River watershed. Korean J. Limnol., 39, 145-156 (in Korean with English summary).

Lang C. and Reymond O., 1995. An improved index of environmental quality for Swiss rivers based on benthic invertebrates. Aquat. Sci., 57, 172-180.

Lang C., l'Eplattenier G. and Reymond O., 1989. Water quality in rivers of Western Switzerland: application of an adaptable index based on benthic invertebrates. Aquat. Sci., 51, 224-234.

Lee C.L., 2001. Ichthyofauna and fish community from the Gap Stream water system, Korea. Korean J. Environ. Biol., 19, 292-301.

Lee J.H. and An K.-G., 2007. Seasonal dynamics of fish fauna and compositions in the Gap Stream along with conventional water quality. Korean J. Limnol., 40, 503-510.
Lee J.H. and An K.-G., 2010. Analysis of various ecological parameters from molecular to community level for ecological health assessments. Korean J. Limnol., 43, 24-34 (in Korean with English summary).

Lee W.O. and No S.Y., 2006. Freshwater fishes of Korea based on characteristics: illustrated book, Jisungsa, Seoul, 432 p. (in Korean with English summary).

Legendre P. and Legendre L., 1998. Numerical ecology (developments in environmental modelling), 2nd English edn., Elsevier, Amsterdam.

Leidy R.A. and Fiedler P.L., 1985. Human disturbance and patterns of fish species diversity in the San Francisco Bay Drainage. Biol. Conserv., 33, 247-267.

Limburg K.E. and Schmidt R.E., 1990. Patterns of fish spawning in Hudson River tributaries: response to an urban gradient. Ecology, 71, 1231-1245.

Lyons J., Navarro-Perez S., Cochran P.A., Santana E. and Guzman-Arroyo M., 1995. Index of biotic integrity based on fish assemblages for the conservation of streams and rivers in west-central Mexico. Conserv. Biol., 9, 569-584.

Maezono Y. and Miyashita T., 2004. Impact of exotic fish removal on native communities in farm ponds. Ecol. Res., 19, 263-267.

McCune B. and Mefford M.J., 1999. PC-ORD. Multivariate analysis of ecological data, Version 4.0, MjM Software, Gleneden Beach, OR.

MOE, 2000. Standard methods for the examination of water quality contamination, 7th edn., Gwacheon, Korea, 435 p. (in Korean).

MOE/NIER, 2006. Researches for integrative assessment methodology of aquatic environments (III): development of aquatic ecosystem health assessment and evaluation system, The Ministry of Environment/National Institute of Environmental Research (NIER), Incheon, Korea (in Korean).

MOE/NIER, 2008. The survey and evaluation of aquatic ecosystem health in Korea, The Ministry of Environment/ National Institute of Environmental Research, Incheon, Korea (in Korean with English summary).

Morley S.A. and Karr J.R., 2002. Assessing and restoring the health of urban streams in the Puget Sound basin. Conserv. Biol., 16, 1498-1509.

Nam M.M., 1996. Present status of Korean freshwater fish. In: 1996 Symposium of Korean Journal of Limnology Proc., 31-45 (in Korean).

Nurnberg G.K., 1996. Trophic state of clear and colored, softand hard-water lakes with special consideration of nutrients, anoxia, phytoplankton and fish. Lake Reservoir Manage., 12, 432-447.

Ohio EPA, 1989. Biological Criteria for the Protection of Aquatic Life (Vol. III): Standardized Biological Field Sampling and Laboratory Method for Assessing Fish and Macroinvertebrate Communities, Columbus, $\mathrm{OH}$.

Olguin H.G., Salibian A. and Puig A., 2000. Comparative sensitivity of Scenedesmus acutus and Chlorella pyrenoidosa as sentinel organisms for aquatic ecotoxicity assessment: studies on a highly polluted urban river. Environ. Toxicol., $15,14-22$.

Plafkin J.L., Barbour M.T., Porter K.D., Gross S.K. and Hughes R.M., 1989. Rapid bioassessment protocols for use in streams and rivers: benthic macroinvertebrate and fish, 
EPA/444/4-89-001, Office of water regulations and standards, US EPA, Washington, DC.

Prepas E.E. and Rigler F.A. 1982. Improvements in qualifying the phosphorus concentration in lake water. Can. J. Fish. Aquat. Sci., 39, 822-829.

Rankin E.T. and Yoder C.O., 1999. Adjustments to the index of biotic integrity: a summary of Ohio experiences and some suggested modifications. In: Simon T.P. (ed.), Assessing the Sustainability and Biological Integrity of Water Resources Using Fish Communities, CRC Press, Boca Raton, FL, 672 p.

Raven P.J., Holmes N.T.H., Dawson F.H., Fox P.J.A., Everard M., Fozzard I.R. and Rowen K.J., 1998. River Habitat Quality: The Physical Character of Rivers and Streams in the UK and Isle of Man, Environment Agency, Bristol.

Rossano E.M., 1996. Diagnosis of Stream Environments with Index of Biological Integrity, Sankaido Publishers, Tokyo.

Sanders R.E., Miltner R.J., Yoder C.O. and Rankin E.T., 1999. The use of external deformities, erosion, lesions, tumors (DELT anomalies) in fish assemblages for characterizing aquatic resources: a case study of seven Ohio streams. In: Simon T.P. (eds.), Assessing the Sustainability and Biological Integrity of Water Resources Using Fish Communities, CRC Press, Boca Raton, FL, 672 p.

Soto-Galera E., Díaz-Pardo E., López-López E. and Lyons J., 1998. Fish indicator of environmental quality in the Río Lerna Basin, México. Aquat. Ecosys. Health Manage., 1, 267-276.

SPSS, 2004. SPSS 12.0 KO for Windows, Apache Software Foundation, Chicago, IL.

Strahler A.N., 1957. Quantitative analysis of watershed geomorphology. Trans. Am. Geophys. Union, 38, 913-920.

US EPA, 1993. Fish Field and Laboratory Methods for Evaluating the Biological Integrity of Surface Waters. EPA 600-R-92-111. Environmental Monitoring Systems Laboratory - Cincinnati office of Modeling, Monitoring
Systems, and Quality Assurance Office of Research Development, US EPA, Cincinnati, OH.

US EPA, 1994. Environmental monitoring and assessment program: integrated quality assurance project plan for the Surface Waters Resource Group. 1994 activities, Rev.2.00. EPA 600/X-91/080, US EPA, Las Vegas, NV.

US EPA, 1998. Lake and reservoir bioassessment and biocriteria technical guidance document, EP-841-B-98-007, US EPA, Office of Water, Washington, DC.

US EPA, 2002. Biological Assessments and Criteria, EPA 822-F02-006, US EPA, Office of Water, Washington, DC.

Walton B.M., Salling M., Wyles J. and Wolin J., 2007. Biological integrity in urban streams: toward resolving multiple dimensions of urbanization. Landscape Urban Plan., 79, 110-123.

Winget R.N. and Mangum F.A., 1979. Biotic condition index: integrated biological, physical, and chemical stream parameters for management, Forest Service, Intermountain region, U.S. Department of Agriculture, Ogden, UT.

Won D.H., Jun Y.C., Kwon S.J., Hwang S.J., An K.-G. and Lee J.K., 2006. Development of Korean saprobic index using benthic macroinvertebrates and its application to biological stream environment assessment. J. Korean Water Qual., 22, 768-783 (in Korean with English summary).

Yeom D.H., An K.-G., Hong Y.P. and Lee S.K., 2000. Assessment of an index of biological integrity (IBI) using fish assemblages in Keum-Ho River, Korea. Korean J. Environ. Biol., 18, 215-226 (in Korean with English summary).

Yoder C.O., 1991. The Integrated Biosurvey as a Tool for Evaluation of Aquatic Life Use Attainment and Impairment in Ohio Surface Waters, EPA/440/5-91/005, US EPA, Washington, DC, 110-122.

Zhu D. and Chang J., 2008. Annual variations of biotic integrity in the upper Yangtze River using an adapted index of biotic integrity (IBI). Ecol. Indic., 8, 564-572. 